\title{
"Exploring the Vark Learning Styles of Islamic Junior High School Students"
}

\author{
Lia Haryana ${ }^{1}$, Titin Astina ${ }^{2}$ and Haris Kurniawati ${ }^{3}$ \\ ${ }^{1}$ Department of English Language Teaching (ELT), Universitas Negeri Malang (UM), Indonesia \\ ${ }^{2,3}$ Universitas Gajah Mada (UGM), Indonesia
}

\begin{abstract}
Knowing the learning styles is very important for both students and the teachers to make the appropriateness between students' preferred ways of learning and teachers' teaching strategies. However, most students do not aware of their learning styles, so do the teachers. Many studies on students' learning styles have been done in many parts of the world. However, the studies of students' learning styles for Islamic school has not been adequately explored or quite rare. For that reason, this research aims to investigate the learning styles of Islamic high school students in Indonesia. This research was accomplished by doing a survey. The data were collected by using a questionnaire adapted from the VARK questionnaire that was developed by Flemming (2006). It consists of four types of learning styles, namely Visual, Auditory, Read/Write, and Kinesthetic. Moreover, the data had been analyzed descriptively. The result showed that the majority of the students in Islamic high school are visual learners which means the majority of them tend to be more active and participative when the teaching and learning process are taught or delivered by using audio learning materials, then it was followed by visual and kinesthetic learning style and read/write learning styles as the least preferred learning style. The result of this study can be used as the guideline for the teachers of other Islamic schools to create a learning environment to be more appropriate for audio learners.
\end{abstract}

Keywords: Effective Learning, Islamic Junior High School, Learning Styles, VARK

\section{Introduction}

The quality of the teaching and learning process depends on several factors. Some of those factors are learning environment where the teaching and learning process is taking place, teachers' qualifications in which they are considered as the main actor in the classroom, the teaching materials, and students' preferred way of learning. Among these factors, students' preferred way of learning is one of the intriguing topics recently. Students tend to have various preferences and their own best way to learn a language. These preferences of learning refer to the students' learning styles. Buali, et al (2013) stated that learning style refers to a person's learning preferences in apprehending, organizing, and processing information and learning experiences. Learning styles are considered as an important factor in the learning process that has great potential to facilitate learning for students (Babbage, Byers, \& Redding, 1999; Kazu, 2009). Due to various learning styles, the students' process of learning will be various as well. It means that one student will have different ways of comprehending and understanding the teaching materials. This idea is also supported by Battalio (2009) who stated that each individual has their learning style, which will help them to learn information easier through appropriate learning environments and materials. Good quality of education and skill development can be achieved easily through multifaceted learning experiences compatible with students' learning styles and in which they can have an active role (Benner, Sutphen, Leonard \& Day).

Those differences in learning style will affect the students' motivation and attitude toward the learning process as well as the lessons. There is a tendency that the students will be more motivated and have a good 
attitude to learn the lesson when the teaching strategies applied are appropriate with their preferences. When they have high motivation, there is a tendency their achievement will be high as well. For that reason, knowing the learning styles is very important for students to make them realize what ways of learning they like to do. However, most of them do not aware of their learning style (Sasi, 2014), as a result, they tend to get difficulties in understanding the lessons deeply and also achieving high learning achievement.

Furthermore, the idea of the importance of understanding learning styles is also supported by Kazu (2009) who said it is important for individuals to know their preferred/favorite ways of learning because it will make the learning process becomes more effective. By knowing and applying appropriate learning styles that suit their learning preferences, the students tend to perform better in the learning activities. Besides, they can also obtain more information by themselves, as a result, they can increase their knowledge easily and achieve better achievement. Besides the students, the teachers as the main instruments in the classroom also need to know the students' learning styles. It is in line with Hooda \& Lenka (2013) who said it is important for the teachers to know what style of the students for learning in general and particular content. By knowing the students' learning style, the teachers can guide the student in the learning process easier. In line with this idea, teachers must consider students' learning styles and modify their learning strategies accordingly. Inappropriateness between teacher's teaching styles and students' learning styles is considered as one of the major barriers to the learning process in which it happens in most of our learning process, thus the teachers need to employ a variety of methods and learning strategies to present their materials. In other words, they are suggested to accommodate most of the students' learning styles in the classroom.

Research about learning styles has been a fascinating topic nowadays. Studies on this issue have been enacted in many parts of the world, for instance in several countries such as Australia (Rao, 2002); Bahrain (Alkooheji \& Al-Hattami, 2018); Turkey (Kamis \& Ozonur, 2019); United States (Lincoln, F \& Rademacher, B, 2006; Torres, 2014); and Peru (Espinoza-Poves, Miranda-Vilchez, Chafloque-Cespedes, 2019). Hence, it can be concluded that research on this issue remains prominent. Interestingly, the previous studies on students' learning styles are conducted for students of vocational school, business school, college students. Meanwhile, studies on learning styles for the students from the Islamic school has not been adequately explored or quite rare. For those reasons, the researcher is eager to conduct research under the title "Exploring the Vark Learning Styles of Islamic Junior High School Students". This research attempts to identify the learning style preferences of the students in Islamic junior high schools and the most appropriate teaching strategies applied by the teachers to match the students' learning styles.

\section{Method}

A survey design was employed to find answers to the research questions. This study was conducted at one of the Islamic junior high schools in Indonesia. This school is chosen in this study because the researcher got some information from one of the teachers in which the information are used as the reasons, such as most students in this school do not know their learning style preferences, so the students cannot find the most effective way for their learning. Then, there is a tendency that they are not enough interested in learning English. It can be seen from their scores which are included to a low level. Besides, some teachers tend to ignore and do not care about the students learning styles, so whenever they teach they do not implement the teaching strategies that are appropriate with the students' learning styles.

A questionnaire was used as the main instrument, adapted from the VARK questionnaire that was developed by Flemming (2006). There were 15 items in the questionnaire covering four types of learning styles: Visual, Auditory, Read/Write, and Kinesthetic. The questionnaire was spread to the research subjects directly. A stepby-step instruction was provided to enable the subjects to respond to the questionnaire easily. Their responses to

the questionnaire were summarized and then analyzed descriptively to reveal the data and the overall spreads of the scores [1]. 


\section{Findings}

TABLE I. Frequency of students' choices for their preferred learning style

\begin{tabular}{ccccc}
\hline \hline Learning Style & Visual & Auditory & Read/Write & Kinesthetic \\
Q1 & 4 & 15 & 1 & 1 \\
Q2 & 4 & 17 & 0 & 0 \\
Q3 & 1 & 13 & 6 & 2 \\
Q4 & 9 & 1 & 9 & 2 \\
Q5 & 14 & 3 & 1 & 2 \\
Q6 & 10 & 1 & 8 & 6 \\
Q7 & 7 & 1 & 7 & 4 \\
Q8 & 0 & 16 & 0 & 16 \\
Q9 & 0 & 3 & 1 & 1 \\
Q10 & 12 & 1 & 8 & 0 \\
Q11 & 0 & 10 & 10 & 3 \\
Q12 & 0 & 17 & 0 & 3 \\
Q13 & 7 & 9 & 1 & 14 \\
Q14 & 4 & 0 & 4 & 9 \\
Q15 & 4 & 7 & 1 & 64 \\
Total & $\mathbf{7 6}$ & $\mathbf{1 1 4}$ & 57 & . \\
\hline \hline
\end{tabular}

TABLE 1 reveals the number of choices for each option per question. The most chosen learning style preference is auditory, followed by visual, kinesthetic, and read/write. The differences between the four are quite huge, which means the majority of the students are auditory learners and visual learners.

TABLE II. Frequency of students learning style

\begin{tabular}{lllll}
\hline \hline Learning Style & Visual & Auditory & Read/Write & Kinesthetic \\
Percentage & $25 \%$ & $42 \%$ & $12 \%$ & $21 \%$ \\
\hline \hline
\end{tabular}

As can be seen in TABLE 2, it can be concluded that the majority of the students are auditory learners in which it was chosen by $42 \%$ of the respondents, it can be concluded that auditory learning style is the most preferred learning styles of the students in Islamic junior high school. Then it was followed by visual which was chosen by $25 \%$ of the respondents. Followed by kinesthetic which was chosen by $21 \%$ of the respondents. The last learning style was read/write learning style which was chosen by $12 \%$ of respondents, it is the least preferred learning style.

TABLE III Survey questions according to learning preferences chosen and type of activity inquired about

\begin{tabular}{|c|c|c|c|}
\hline Visual & Auditory & "Reading/Writing & Kinesthetic \\
\hline \multirow[t]{3}{*}{$\begin{array}{l}\text { Q11: Decision for watching } \\
\text { a movie }\end{array}$} & Q2: Giving direction & $\begin{array}{l}\text { Q9: Learning a new } \\
\text { computer game }\end{array}$ & $\begin{array}{l}\text { Q5: Decision doing } \\
\text { something }\end{array}$ \\
\hline & $\begin{array}{l}\text { Q8: Giving instruction } \\
\text { Q12: Teachers' instruction }\end{array}$ & $\begin{array}{l}\text { Q14: Tasting new food } \\
\text { menu }\end{array}$ & $\begin{array}{l}\text { Q6: Decision regarding } \\
\text { buying a new digital } \\
\text { camera or mobile phone }\end{array}$ \\
\hline & & & $\begin{array}{l}\text { Q10: Decision for buying } \\
\text { new books }\end{array}$ \\
\hline $\begin{array}{l}\text { Items related to: } \\
\text { Technology }\end{array}$ & $\begin{array}{l}\text { Items related to: } \\
\text { Giving instructions }\end{array}$ & $\begin{array}{l}\text { Items related to: } \\
\text { Trying something new }\end{array}$ & $\begin{array}{l}\text { Items related to: } \\
\text { Action on doing something }\end{array}$ \\
\hline
\end{tabular}

TABLE 3 reveals the types of students' favorite activities based on their learning styles. As can be seen in the visual learning style, the most chosen question was number 11, which relates to the use of technology. Moreover, in the auditory learning style, the most chosen questions were questions number 2, 8, and 12 in which those questions relate to giving instruction and direction. Furthermore, in reading/writing learning style, the most chosen questions were questions number 9 and 14 in which both questions relate to the way of trying something new. Besides, in the kinesthetic learning style, the most chosen questions were questions number 5, 6, and 10 in which the questions relate to the way or action on doing something. 
TABLE IV. Frequency of students' choices for their preferred learning style by gender

\begin{tabular}{lllllllll}
\hline Learning & \multicolumn{2}{c}{ Visual } & \multicolumn{2}{c}{ Auditory } & \multicolumn{2}{c}{ Read/Write } & \multicolumn{2}{c}{ Kinesthetic } \\
Style & & & & & & \\
Gender & Male & Female & Male & Female & Male & Female & Male & Female \\
Percentage & $15 \%$ & $8 \%$ & $11 \%$ & $30 \%$ & $3 \%$ & $8 \%$ & $8 \%$ & $15 \%$ \\
\hline
\end{tabular}

From the TABLE 4, it can be concluded that the male students' learning style is visual which was chosen by $15 \%$ of the respondents, followed by auditory learning style which was chosen by $11 \%$ of the respondents, then followed by kinesthetic which was chosen by $8 \%$ of the respondents and the last one is read/write which was chosen by only $3 \%$ of the respondents. Meanwhile, the female students' learning style is auditory which was chosen by $30 \%$ of the respondents, then followed by kinesthetic learning style which was chosen by $15 \%$ of the female respondents. Then followed by visual and read/write which were chosen by the same amount of the students, which was $8 \%$ of the respondents. Based on that results, it can be concluded that the majority of the male students are visual learners, then followed by auditory learners, and the majority of the female students are auditory. In addition, both male and female students are auditory learners. Meanwhile, the least preferred learning style of both male and female students are read/write learning style.

\section{Discussion}

Based on the research result, the most dominant learning style adopted by the students is the auditory learning style. This style proved that the students of Islamic junior high school can learn productively by listening to the teachers' explanation and instruction. Besides they also have a higher ability to learn from class discussion and conversing with tutors. The information about students' learning styles can be used by the teachers as the sources of information about their students and the proof that their students have different preferences in which the teachers can select the most appropriate learning methods and assessment strategies. Besides, the information can be used for helping the students to better understand their strengths and weaknesses in the learning process then the good achievement can be reached through increasing the strengths and improving the weaknesses. This idea is supported by Sulaiman \& Jasmi (2018) who stated that the learning styles of each student are important as it has a strong influence in the academic outcome and mandated a correct mechanism that challenges the student ability simultaneously to provide guided feedback of their achievements. Besides, students can plan and manage their language learning activities better if they can discover their preferred learning styles. Once the students distinguish and know their learning styles they can find suitable activities that suit their learning preferences which will enhance their performance in learning. In addition, if the students fail to identify their preferred or compatible learning styles, they might lose interest in learning English as they fail to find suitable activities that can boost their learning interest.

When the learning styles of the students in one class and teaching styles of the teachers are mismatched, with hostile potential effects, the students may be bored and become distracted in class, perform badly in test, get disheartened about the course, the curriculum and themselves and many cases the students tend to change to another program or drop out from school (Felder \& Spurlin, 2005). Due to those reasons, students' learning styles and teachers teaching strategies are the factors determining the quality of the teaching and learning process. They should be matched with each other. The teachers as the key instruments in the class should create a learning environment that is appropriate for the students. To provide a viable educational environment for all students, one of the ways is the teachers should try to identify the learning styles of their students, match their teaching style to students' learning styles by giving middle or difficult tasks, and strengthen the least preferred learning styles by giving easier tasks and drills.

Previous investigations have identified that the elements of the learning environment that are under teachers' control, positively influence both the way students approach their study, and the learning outcomes they may achieve (Lizzio, Wilson, \& Simons, 2002. Furthermore, this idea is also supported by Flemming \& Bonwell (1998) who stated it is considerably easier to change learning and teaching strategy than to attempt to change the learners' learning preferences. However, there are opportunities for individuals to change their 
learning preferences with age or life experience. Moreover, some research findings also have demonstrated that when teaching style/teaching strategies are compatible with student learning styles, students could retain information longer, apply it more effectively, have a more positive attitude to their subjects and are greater achievers (Boles, Pillay \& Raj, 1999; Charkins, O’Toole \& Wetzel, 1985).

Regarding the most preferred learning styles of the students in this research is auditory learning styles and then followed by visual learning styles, these are some activities that the teachers can implement in the classroom. For auditory learning styles, such as listening exercises of a dialogues, exercising cloze test using a slow song/ poem from the teacher or the audiotapes, listening to English podcasts, then practicing some vocabularies that are found in the podcasts, reading aloud, doing peer interview, doing group discussion to solve certain problem given by the teacher; lecturing by the teacher or doing peer-tutoring to reinforce new information. Moreover, for visual learning styles, such as reading resources for new information, watching an action kit or seeing some pictures/texts, then writing narrative events; and taking notes of the teachers' explanation, then comparing the notes with others to reinforce ideas.

However, students study differently. It is supported by Man \& Tomoko (2010) who stated that what works well for one student may not be beneficial or favorable to another. Individuals learn differently in many ways from time to time, from culture to culture and from context to context. Then, matching each of the students' learning styles and teachers' teaching strategies is quite hard. As we know, the majority of the students are auditory learners and visual learners, what the teachers can do is creating a comfortable classroom environment for all students so they can learn better. In addition, the teacher can vary the teaching instructions or techniques by combining two types of teaching strategies that are appropriate for both auditory learners and visual learners.

\section{Conclusion}

From the research findings, few suggestions to improve and reduce the differential gap on the constant usage of learning styles of Islamic junior high school students so that the motivational level of students remain significantly high towards the teaching and learning. Those suggestions are intended for the students, for the teachers, and the students' parents. For the students, they are required to identify their unique learning styles through consultation with the school counselor or guru $B K$ and the students are also informed and guided on the importance of learning styles concerning their learning processes.

For the teachers, they need to improvise various teaching techniques, approaches to lesson, teaching, and learning materials and create activities to inspire student to their optimum learning level; teachers need to maintain a high level of professionalism in coaching, tutoring, supporting and motivating students; teachers have to evaluate and explore the student's attitude and keenest toward studies periodically from time to time; teachers should create a lively and cheerful learning ambiance and surrounding and stimulate the student by the aptitude and ability towards study; teachers have to improve the quality of teaching materials that suitable with the learning styles of student for the particular subject; school counselor and guidance teacher need to maintain and to help to upkeep a proper record to identity the learning styles of students.

For the parents, they have to instill the importance and need of their child to be independent and responsible learner to face the ever-changing education landscape from time to time; the parents have to give full support towards school in fulfilling the requirement of their child educational needs, and the parents have to provide the physical needs of their child to compliment the learning style of their child.

Based on the research result, there is a different learning style based on gender. The male students preferred the visual learning style. Meanwhile, female students preferred the audio learning style. However, when they are combined, the most preferred learning style was the auditory learning style. 


\section{Acknowledgements}

I am enormously grateful to LPDP (Lembaga Pengelola Dana Pendidikan-Indonesia Endowment Fund for Education) as my sponsorship in pursuing my study and also supporting the funding for participating in this conference.

\section{References}

[1] Babbage, R., Byers, R., \& Redding, H. (1999). Approaches to Teaching and Learning - including pupils with learning difficulties. London: David Fulton Publisher.

[2] Battalio, J. (2009). Success in distance education: Do learning styles and multiple formats matter?,The American Journal of Distance Education (23:2), 71-87.

https://doi.org/10.1080/08923640902854405

[3] Benner, P., Sutphen, M., Leonard, V., \& Day, L. (2010). Education nurses: A call for radical transformation. San Francisco, CA: Jossey- Bass.

[4] Boles, W., Pillay, H., \& Raj, L. (1999). Marching cognitive styles to computer-based instruction. An approach for enhanced learning in electrical engineering. European Journal of Engineering Education, (24), 371-383. https://doi.org/10.1080/03043799908923572

[5] Buali, W., H., A., Balaha, M., H. \& Muhaidab, N., S. (2013). Assessment of learning style in a sample of Saudi medical students. Assessment of Learning Style in a Sample of Saudi Medical Students (21) 83-88. https://doi.org/10.5455/aim.2013.21.83-88

[6] Charkins, R.J., O’Toole, D.M., \& Wetzel, J.N. (1985). Linking teaching and student learning styles with student achievement and attitudes. Journal of Economic Education, (16), 111-120.

https://doi.org/10.1080/00220485.1985.10845106

[7] Dornyei, Z. (2003). Questionnaires in second language research: Constructing, administering, and processing. Mahwah, NJ: Lawrence Erlbaum Associates.

[8] Felder, R. M. \& Spurlin, J. E. (2005). Applications, reliability, and validity of the Index of Learning Styles. International Journal of Engineering Education, 21 (1), 103-112, 2005.

[9] Fleming, N. \& Bonwell, C. (1998). VARK: A guide to learning styles. http://www.vark learn.com/english/index.asp

[10] Fleming, N.D. 2008. VARK. A Guide to Learning Styles. The VARK Questionnaire.

[11] Hooda, P., \& Lenka, S. K. (2013). "Importance of learning style magnitude in education". International Journal of Research in Economics \& Social Sciences: Volume 3, Issue 1 Page 35-44 ISSN: 2249-7382

[12] Kamish, H \& Ozonur, M. (2019). Students' learning styles in vocational education. International Journal of Curriculum and Instruction 11 (1), 209-220. ISSN: EISSN-1562-0506

[13] Kazu, I. Y. (2009). The effect of learning styles on education and the teaching process. Turkey: Firat University. Journal of Social Sciences 5(2): 85-94, 2009: ISSN 1549-3652. https://doi.org/10.3844/jssp.2009.85.94

[14] Lincoln, F \& Rademacher, B. (2006). Learning styles of ESL students in community colleges. Community College Journal of Research and Practice, 30 (5-6), 485-500, DOI: 10.1080/10668920500207965

[15] Lizzio, A., Wilson, K. and Simons, R. (2002). University students' perceptions of the learning environment and academic outcomes: Implications for theory and practice. Studies in Higher Education 27 (1), 27-50 https://doi.org/10.1080/03075070120099359

[16] Man, P.C. \& Tomoko, N. (2010). A study of Chinese and Japanese college students' L2 learning styles. Asian Culture and History 2 (2), 30- 35. https://doi.org/10.5539/ach.v2n2p30

[17] Rao, Z. (2002). A close look at the Chinese cultural influence on students' learning styles and strategies. Asian Englishes, 5 (1), 40-63, DOI: 10.1080/13488678.2002.10801088

[18] Sasi, D., A. (2014). The correlation study between learning style and learning outcome of the first-year students in the structure analysis class at the study program of English. Malang: Universitas Brawijya. 
[19] Sulaiman, Z., \& Jasmi, K. A. (2018). Learning style practiced by students in Andalus Islamic Education Centre, Singapore. International Journal of Academic Research in Education and Progressive Development, 7(3), 441-452.

[20] Torres, S. M. (2013). The relationship between Latino students' learning styles and their academic performance. Community College Journal of Research and Practice. 38:4, 357-369, DOI: 10.1080/10668926.2012.761072 